\title{
ANALISIS PEMILIHAN KOST IDEAL KHUSUS PUTRA DENGAN PEMERINGKATAN MENGGUNAKAN METODE TOPSIS
}

\author{
Indra Riyana Rahadjeng \\ Universitas Bina Sarana Informatika \\ riyana.irrebsi.ac.id
}

\begin{abstract}
Decision making must of course be based on several factors that have a positive or no detrimental effect later. Therefore, careful calculations and considerations are required. This decisionmaking can occur in every human life, one of which is in deciding a temporary residence or boarding house for students who are studying outside the city. In this study, the selection of the ideal male boarding house was chosen as the object of research by using several factors as consideration. . Among them are the facilities provided, the balance of costs, distance, comfort level, security, and cleanliness. One solution to make it easier for students to choose and determine the appropriate, ideal and appropriate boarding house is to use decision support that can be done using the TOPSIS (Technique Order Preference by Similarity To Ideal Solution) method. This method is based on various concepts of the best alternative provided that it has the shortest distance to the positive ideal solution and the longest distance to the negative ideal solution. The researchers ranked and the result was that A2 boarding house was ranked the highest as the boarding house that best matched the search criteria so that it could be an alternative for students to choose after calculating using the TOPSIS method.
\end{abstract}

Keywords - Decision Making; boys' boarding house; TOPSIS.

\begin{abstract}
Abstrak - Pengambilan keputusan tentunya harus berdasarkan kepada beberapa faktor yang memberikan efek positif atau tidak merugikan nantinya. Sehingga diperlukan berbagai perhitungan dan pertimbangan yang matang. Pengambilan kpeutusan ini dapat terjadi pada setiap kehidupan manusia salah satunya adalah dalam memutuskan tempat tinggal sementara atau kost bagi para mahasiswa yang sedang menempuh pendidikan di luar kota, Pada penelitian ini, pemilihan kost khusus putra yang ideal dipilih sebagai objek penelitian dengan menggunakan beberapa faktor sebagai bahan pertimbangan. Diantaranya adalah fasilitas yang diberikan, keseimbangan biaya, jarak, tingkat kenyamanan, keamanan, dan kebersihan. Salah satu solusi untuk memudahkan mahasiswa dalam memilih dan menentukan kost yang sesuai, ideal dan tepat adalah dengan menggunakan pendukung pemilihan keputusan yang dapat dilakukan dengan menggunakan metode TOPSIS (Technique Order Preference by Similarity To Ideal Solution). Metode ini didasarkan pada berbagai konsep alternatif yang terbaik dengan ketentuan memiliki jarak paling pendek pada solusi ideal positif dan memiliki jarak paling panjang ke solusi ideal negatif. Peneliti melakukan pemeringkatan dan hasilnya kost A2 menempati peringkat tertinggi sebagai kost yang paling sesuai dengan kriteria pencarian sehingga dapat menjadi alternatif untuk dipilih oleh mahasiswa setelah dilakukan perhitungan menggunakan metode TOPSIS.
\end{abstract}

Kata Kunci - Sistem Pendukung Keputusan, kost putra, TOPSIS.

\section{PENDAHULUAN}

Setiap pemilihan suatu keputusan harus disertai dengan beberapa pertimbangan dengan mengandalkan berbagai alternatif melaui proses tertentu agar mendapatkan hasil yang tepat. Pemilihan keputusan ini bisa saja muncul pada berbagai kegiatan dalam kehidupan manusia salah satunya adalah memilih hunian sementara atau kost. Dimana Kost menjadi kebutuhan primer khususnya bagi mahasiswa yang datang dari luar kota dan menuntut ilmu di kota lain. Saat memilih tempat tinggal sementara atau kost ini, sering dijumpai beberapa kendala dimana mahasiswa tentunya menginginkan kost yang tepat dan sesuai dengan keinginan mereka [1]. Sehingga, dalam pemilihan kost ini tentu saja tak lepas dari adanya kriteria-kriteria pendukung yang dibutuhkan mahasiswa untuk nantinya dijadikan sebagai acuan dalam pemilihan tempat kost ini.
Hampir seluruh mahasiswa mengalami kesulitan dalam mendapatkan kamar kost ini, tak terkecuali juga khususnya pada mahasiswa laki-laki yang sedang menimba ilmu di perguruan tinggi daerah Depok sehingga mengharuskan mereka mencari tempat tinggal sementara selama menempuh pendidikan disana. Untuk mahasiswa yang datang dari luar kota, tidak aneh jika banyak mahasiswa belum mengenal seluk beluk dan berbagai daerah di kota-kota yang akan ditinggali oleh mereka nantinya. Khususnya untuk mereka yang datang dari luar kota dan tidak memiliki teman ataupun saudara dikota tujuan, menjadikan mereka kekurangan informasi sehingga mereka akan cenderung memilih tempat kost yang dekat dengan kampus. Setidaknya ada enam kriteria umum yang dapat dijadikan acuan dan bahan pertimbangan bagi mahasiswa dalam mencari tempat tinggal sementara atau kost, diantaranya adalah fasilitas yang diberikan; keseimbangan biaya hidup, 
harga kost dan uang saku; jarak tempuh ke kampus; kenyamanan; keamanan; dan yang terakhir juga paling penting adalah kebersihannya [2].

Era globalisasi dan digitalisasi saat ini, sangat membantu dan berperan penting dalam kehidupan seahari-hari manusia. Dengan berbagai kemajuan teknologi dan informasi ini, kesulitan mahasiswa dalam memilih dan menentukan tempat kost yang tepat dapat terpenuhi dan terbantu. Selain itu, kemajuan teknologi dan infotmasi ini tentunya akan sangat membantu baik dari sisi pemilik kost maupun pihak penyewa yang disni merupakan para mahasiswa [3]. Melalui pemanfaatan teknologi internet, para pemilik tempat kost dapat menggunakan sosial media untuk mempromosikan kost yang akan mereka sewakan dengan memberikan berbagai gambar dan keterangan sehingga memudahkan mahasiswa sebagai calon penyewa untuk mengetahui kost dan tampilannya tanpa perlu kesulitan bolak balik mendatangi kost satu dan yang lainnya [4].

Dengan mengacu kepada berbagai kriteria diatas, maka dibutuhkan suatu sistem pendukung keputusan guna membantu para mahasiswa khususnya mahasiswa laki-laki yang sedang mencari tempat kost yang tepat sesuai kriteria yakni mencari tempat kost khusus putra. Sistem Pendukung Keputusan ini sendiri dapat didefinisikan sebagai sebuah sistem yang membantu mahasiswa dalam menentukan dan mengambil keputusan dengan memanfaatkan berbagai pendukung yang diantaranya berupa computer. Sehingga dengan menggunakan sistem ini, dapat mempermudah mahasiswa dalam pengambilan keputusan. Sistem pendukung keputusan ini juga dapat diartikan sebagai pengambilan keputusan berdasarkan beberapa kretiria sehingga dapat mengambil keputusan yang manajerial pada situasi yang semi terstruktur [5].

Meski tidakiisecara khusus dinyatakan dalam pengertian tadi, namun secara tersirat dapat disimpulkan bahwa sistem yang digunakan akan berbasis komputer sehingga mahasiswa sebagai penggunanya akan menggunakan komputer berbasis yang dioperasikan dengan pemanfaatan teknologi internet interaktif yang juga lebih disukai dengan memiliki kemampuan hasil atau output berupa grafis [6]. Dalam menggunakan sistem pendukung keputusan ini, dibangun berdasarkan beberapa langkah seperti diawali dengan melakukan identigfiksi, memilih data yang relevan, melakukan pendekatan ketika melakukan proses pengambilan keputusan akan membantu mahasiswa dalam mendatkan hasil dari evaluasi yang alternatif [7]

Sistem pengambilan keputusan juga sangat erat kaitannya dengan sistem informasi yang secara spesifik digunakan dalam membantu manajemen untuk mengambil sebuah keputusan yang memiliki yang memiliki berbagai keterkaitan dan kesinambungan dengan hal yang memiliki sifat semi terstruktur secara efektif dan efisien [8]. Meskipun menggunakan sebuah sistem, namun tentunya tidak menggantikan fungsi pada pengambilan keputusan itu sendiri jika dilakukan pengambilan keputusan secara manual.

Dalam penggunaannya, mahasiswa dapat merasakan berbagai manfaat dan kelebihan yang dimiliki oleh sistem pengambilan keputusan ini, seperti diantaranya dapat lebih menghemat waktu sehingga lebih efektif ketika sedang memilih dan mengambil keputusan khususnya dalam mencari tempat tinggal sementara yang tepat dan sesuai dengan keinginan. Manfaat kedua adalah semakin menguatkan dan memberikan rasa yakin terhadap mahasiswa dalam melakukan pengambilan keputusan pada satu buah pilihan keputusan yang akan diambil juga mampu menghasilkan sebiuah hasil berupa solusi yang maksimal dan tentunya dapat langsung digunakan dengan lebih cepat [9].

Dalam melakukan pengambilan keputusan menggunakan sistem pendukung pengambilan keputusan, maka terdapat berbagai jenis-jenis metode yang dapat dilakuakn diantaranya adalah Analytical Hierarchy Process (AHP), Simple Additive Weighting (SAW), Weighted Product (WP), Moora, Electre, dan Technique for Order Preference by Similarity to Ideal Solution (TOPSIS). Pada penelitian ini, peneliti memilih untuk melakukan pengambilan keputusan pada pemilihan kost khusus putra dengan menggunakan metode TOPSIS. Metode ini dipilih karena dianggap paling cocok untuk digunakan dalam menentukan kost khusus putra yang tepat dan ideal dengan tidak lupa dilakukan perhitungan pada beberapa kriteria berupa jarak, kebersihan, fasilitas, kenyamanan, biaya, dan keamanan [4]. Pada penggunaannya, sistem pendukung pemilihan keputusan dengan menggunakan metode TOPSIS ini berdasar pada berbagai konsep alternatif yang terbaik dengan jarak terhadap solusi ideal positif paling pendek dan jarak dengan solusi ideal negatif paling panjang. Keunggulan dari penggunaan metode pemilihan keputusan menggunakan TOPSIS adalah konsep sederhana yang dimilikinya lebih mudah difahami, lebih efisien dan juga memiliki kemampuan dalam melakukan pengukuran alternatif. Diharapkan hasil dari penelitian dapat mengimplementasi model pengambilan keputusan dengan menggunakan sistem pendukung pemilihan keputusan yaitu dengan menggunakan metode TOPSIS sehingga dapat membantu memudahkan mahasiswa dalam memilih dan melakukan pengambilan keputusan pada penyeleksian kost disekitar kampus daerah Depok.

\section{METODE PENELITIAN}

Peneliti melakukan pencarian pada berbagai sumber berupa jurnal, artikel, atau buku yang terkait dengan topik penelitian. Pada tahapan studi literature ini peneliti melakukan pengumpulan data terhadap berbagai sumber yang membahas mengenai sistem pendukung keputusan memilih kost khusus putra dengan menggunakan metode TOPSIS [10-11]. 


\section{A. Teknik Pengumpulan Data}

Setelah mendapatkan berbagai data yang bersumber dari buku dan jurnal, selanjutnya peneliti melakukan pengumpulan data yang didapatkan dengan melakukan survei, wawancara dan kuesioner terkait pemilihan kost khusus putra di daerah Depok.

\section{B. Implementasi Metode TOPSIS}

Penelitian ini menggunakan metode TOPSIS yang pada implementasinya membutuhkan input berbagai kriteria diantaranya berupa fasilitas yang diberikan, keseimbangan biaya yang akan dikeluarkan, keamanan, kenyamanan, kebersihan, dan jarak yang ditempuh dari kost ke kampus. Selain itu, terdapat berbagai alternatif keputusan yang dapat diambil saat memilih kost khusus putra di daerah Depok. Alternatif ini dilakukan dengan berbagai cara dan tahapan guna mendapatkan alternatif dalam mendapatkan kost yang terbaik [12-13].

\section{HASIL DAN PEMBAHASAN}

Setelah melakukan pengumpulan data, beberapa nilai penelitian terkait dengan penggunaan sistem pendukung pemilihan keputusan untuk memilih kost khusus putra yang ideal dan tepat di kota Depok. Nurcahyono dan Metandi (2016) menggunakan metode TOPSIS dengan mengumpulkan 10 data tempat kost dengan dua kriteria yaitu 5 diantaranya khusus putra dan 5 diantaranya yang tersisa merupakan kost putri. Dari hasil penelitian, diperoleh satu urutan tertinggi berdasarkan dari kriteria kamar kost terfavorite, kamar kost diurutkan dengan menggunakan kode A1 sampai dengan A10. Sedangkan kamar terfavorit jatuh pada kode kamar A4 dan A8.

Selain untuk menentukan pilihan kost khusus putra, ditemukan pula penggunaan metode TOPSIS pada pemilihan Dosen Berprestasi dengan materi pembahasan berupa pembangunan sistem dengan menggabungkan metode ANP dan metode TOPSIS guna mendapatkan hasil penilaian pemilihan dosen berprestasi yang lebih akurat. Setelah dilakukan penelitian, hasilnya menunjukkan bahwa metode ANP mampu memberikan presentasi akurat mengenai tingkat kepentingan berbagai pihak dengan acuan pertimbangan interpendensi. Lalu selanjutnya dengan menggunakan metode TOPSIS, membantu pengguna dalam menentukan peringkat yang akan diberikan kepada dosen-dosen yang berprestasi dengan hasil yang tentunya akurat dan adil.

\section{A. Pengumpulan Data}

Pengumpulan data dilakukan dengan teknik survei, wawancara dan kuesioner pada responden untuk mengetahui seberapa penting penggunaan sistem pendukung dalam memberikan bantuan pemilihan keputusan penggunanya dengan menggunakan nilai bobot kriteria. Pada penelitian ini dilakukan pengujian pada tiga tempat kost khusus putra terpilih berdasarkan kebutuhan penelitian yakni Kost Putra Pondok Rizki, Kost Griya Putra, dan Kost Putra Al Gifary. Sebagai Kost A1, Kost A2 dan Kost A3.

1) Penghitungan Kriteria yang dibutuhkan

a. Bobot

\begin{tabular}{|c|c|}
\multicolumn{2}{c}{ Tabel 1. Kriteria } \\
\hline Kriteria (C) & Keterangan \\
\hline C1 & Fasilitas \\
\hline C2 & Biaya \\
\hline C3 & Keamanan \\
\hline C4 & Kenyamanan \\
\hline C5 & Kebersihan \\
\hline C6 & Jarak \\
\hline
\end{tabular}

Dari kriteria yang telah ditentukan pada Tabel 1, maka penentuan tingkatan berdasarkan pada kepentingan kriteria tersebut dengan menggunakan nilai bobot. Dibawah ini merupakan nilai bobot yang diberikan pada kriteria yang telah ditentukan melalui kuesioner yang akan diberikan kepada responden:

Tabel 2. Nilai Bobot Kriteria

\begin{tabular}{|c|c|}
\hline Nilai Bobot & Keterangan \\
\hline 1 & Sangat Buruk \\
\hline 2 & Buruk \\
\hline 3 & Cukup \\
\hline 4 & Baik \\
\hline 5 & Sangat Baik \\
\hline
\end{tabular}

Setiap variabel kriteria akan dikonversikan untuk dihitung nilai kecocokannya dengan setiap kriteria alternatif, yaitu sebagai berikut:

\section{b. Kriteria Fasilitas}

Tabel 3. Kriteria Fasilitas

\begin{tabular}{|c|l|}
\hline Nilai & \multicolumn{1}{|c|}{ Fasilitas yang Diberikan } \\
\hline 1 & Tempat tidur, lemari \\
\hline 2 & Tempat tidur, lemari, meja belajar \\
\hline 3 & $\begin{array}{l}\text { Tempat tidur, lemari, meja belajar, kipas } \\
\text { angin }\end{array}$ \\
\hline 4 & $\begin{array}{l}\text { Tempat tidur, lemari, meja belajar, kipas } \\
\text { angin, wifi }\end{array}$ \\
\hline 5 & $\begin{array}{l}\text { Tempat tidur, lemari, meja belajar, kipas } \\
\text { angin, wifi, dapur dan ruang tamu pribadi }\end{array}$ \\
\hline
\end{tabular}

c. Kriteria Biaya

Tabel 4. Kriteria Biaya

\begin{tabular}{|c|c|}
\hline Nilai & Tarif Biaya \\
\hline 1 & $>$ Rp. 1.500 .000 \\
\hline 2 & $<=$ Rp. $1.500 .000>$ Rp. 1.000 .000 \\
\hline 3 & $<=$ Rp. $1.000 .000 .,>$ Rp. 750.000 \\
\hline 4 & $<=$ Rp. $750.000 .,>$ Rp. 500.000 \\
\hline 5 & <=Rp. 500.000 \\
\hline
\end{tabular}




\section{d. Kriteria Keamanan}

Tabel 5. Kriteria Keamanan

\begin{tabular}{|c|l|}
\hline Nilai & \multicolumn{1}{|c|}{ Pemberian Keamanan } \\
\hline 1 & Satpam Kost \\
\hline 2 & $\begin{array}{l}\text { Terdapat kamera pemantau tersembunyi } \\
\text { (CCTV) }\end{array}$ \\
\hline 3 & Satu atap dengan pemilik kost \\
\hline 4 & $\begin{array}{l}\text { Satu atap dengan pemilik kost disertai adanya } \\
\text { kamera pemantau tersembunyi (CCTV) }\end{array}$ \\
\hline 5 & $\begin{array}{l}\text { Satu atap dengan pemilik kost disertai Satpam } \\
\text { kost }\end{array}$ \\
\hline
\end{tabular}

e. Kriteria Kenyamanan

Tabel 6. Kriteria Kenyamanan

\begin{tabular}{|c|l|}
\hline Nilai & \multicolumn{1}{|c|}{ Tingkat Kenyamanan } \\
\hline 1 & $\begin{array}{l}\text { Jaraknya yang dekat dengan kampus, luas } \\
\text { kamar yang cukup }\end{array}$ \\
\hline 2 & $\begin{array}{l}\text { Jaraknya yang dekat dengan kampus dan } \\
\text { warung makan }\end{array}$ \\
\hline 3 & $\begin{array}{l}\text { Jaraknya yang dekat dengan kampus dan } \\
\text { warung makan, minimarket dan pasar }\end{array}$ \\
\hline 4 & $\begin{array}{l}\text { Jaraknya yang dekat dengan kampus dan } \\
\text { warung makan, teras bank dan ATM }\end{array}$ \\
\hline 5 & $\begin{array}{l}\text { Jaraknya yang dekat dengan kampus dan } \\
\text { warung makan, teras bank dan ATM, } \\
\text { supermarket dan pusat kota }\end{array}$ \\
\hline
\end{tabular}

f. Kriteria Kebersihan

Tabel 7. Kriteria Kebersihan

\begin{tabular}{|c|c|}
\hline Nilai & Tingkat Kebersihan \\
\hline 1 & $\begin{array}{l}\text { Kebersihan ditanggung penghuni kost } \\
\text { dengan pemberian jadwal piket }\end{array}$ \\
\hline 2 & $\begin{array}{l}\text { Kebersihan kost ditanggung pihak ketiga } \\
\text { atau cleaning service }\end{array}$ \\
\hline 3 & Kebersihan kost ditanggung pemilik kost \\
\hline 4 & $\begin{array}{l}\text { Kebersihan kost ditanggung pemilik kost dan } \\
\text { penghuni }\end{array}$ \\
\hline 5 & $\begin{array}{l}\text { Kebersihan ditanggung pemilik kost dengan } \\
\text { mendatangkan cleaning service }\end{array}$ \\
\hline
\end{tabular}

g. Kriteria Jarak

Tabel 8. Kriteria Jarak Tempuh

\begin{tabular}{|c|c|}
\hline Nilai & Jarak \\
\hline 1 & $>1000 \mathrm{~m}$ \\
\hline 2 & $=1000 \mathrm{~m}$ \\
\hline 3 & $>750 \mathrm{~m}<1000 \mathrm{~m}$ \\
\hline 4 & $>500 \mathrm{~m}<750 \mathrm{~m}$ \\
\hline 5 & $<500 \mathrm{~m}$ \\
\hline
\end{tabular}

\section{2) Vektor Bobot}

Berdasarkan dari hasil kuesioner yang didapatkan dari responden, peneliti mengambil keputusan untuk memberikan nilai bobot pada hasil jawaban responden dengan berdasarkan pada tingkat kepentingan yang dihasilkan dari setiap criteria, sebagai berikut:
Tabel. 9 Vektor Bobot

\begin{tabular}{|c|c|}
\hline Kriteria (C) & Nilai \\
\hline C1 & 5 \\
\hline C2 & 4 \\
\hline C3 & 3 \\
\hline C4 & 3 \\
\hline C5 & 2 \\
\hline C6 & 2 \\
\hline
\end{tabular}

\section{B. Penggunaan metode TOPSIS}

Setelah dilakukan penelitian, hasilnya berupa sebuah sistem yang nantinya dapat dibangun untuk membantu mahasiswa khususnya mahasiswa laki-laki dalam mencari tempat kost khusus putra yang ideal. Setelah peneliti melakukan pengumpulan data dengan memberikan kuesioner, guna mendapatkan hasil berupa nilai dari tingkat kepentingan setiap kriteria dalam pemilihan kost menggunakan metode TOPSIS diperoleh beberapa peringkat berdasarkan pada kecocokan alternatif yang ditunjukkan oleh setiap kriteria sebagai berikut:

Tabel 10. Peringkat Kecocokan

\begin{tabular}{|l|l|l|l|l|l|l|}
\hline \multicolumn{7}{|c|}{ Nilai Kecocokan } \\
\hline Alternatif & C1 & C2 & C3 & C4 & C5 & C6 \\
\hline A1 & 2 & 4 & 3 & 3 & 3 & 4 \\
\hline A2 & 4 & 3 & 4 & 5 & 4 & 2 \\
\hline A3 & 5 & 3 & 4 & 2 & 5 & 3 \\
\hline
\end{tabular}

Keterangan: A1, A2, A3 merupakan contoh nama tempat kost sebagai alternatif dan C1, C2, C3, C4, C5, C6 merupakan nama kriteria yang dapat dijadikan sebagai acuan dari pemilihan kost. Sehingga peneliti menghitung matriks keputusan yang ternormalisasi sebagai berikut ini:

$$
\begin{aligned}
& |\mathrm{x} 1|=\sqrt{2^{2}+4^{2}}+5^{2}=6,7082 \\
& \mathrm{r}_{11}=\frac{2}{6,7082}=0,2981 \\
& \mathrm{r}_{21}=\frac{4}{6,7082}=0,5963 \\
& \mathrm{r}_{13}=\frac{5}{6,7082}=0,7454
\end{aligned}
$$

dan seterusnya, maka peneliti memperoleh hasil normalisasi sebagai berikut

Tabel 11. Data Hasil Normalisasi

\begin{tabular}{|l|l|l|l|l|l|}
\hline 0.2981 & 0.6068 & 0.4865 & 0.4768 & 0.4342 & 0.7248 \\
\hline 0.5963 & 0.5415 & 0.6472 & 0.8211 & 0.5767 & 0.3147 \\
\hline 0.7475 & 0.5415 & 0.6472 & 0.3422 & 0.7770 & 0.5751 \\
\hline
\end{tabular}

Lalu selanjutnya penulis melakukan penghitungan terhadap matriks ternormalisasi terbobot sehingga diperoleh persamaan bobot ternormalisasi sebagai berikut:

Tabel 12. Bobot Ternormalisasi

\begin{tabular}{|l|l|l|l|l|l|}
\hline 1.4790 & 2.4770 & 1.4065 & 1.6400 & 0.8485 & 1.3626 \\
\hline 2.8149 & 2.8050 & 1.8174 & 2.3433 & 1.2338 & 0.4624 \\
\hline 3.7862 & 2.8050 & 1.8174 & 0.7934 & 1.3245 & 1.1127 \\
\hline
\end{tabular}


Lalu selanjutnya, peneliti akan menentukan matriks untuk solusi ideal positif dan matriks untuk solusi ideal negatif dengan ditunjukkan pada persamaan sebagai berikut:

$$
\begin{aligned}
& \text { A } 1+=\text { MAX }\{1,4790 ; 2,8050 ; 3,7862\}=3,7268 \text { dan } \\
& \text { seterusnya. } \\
& \text { A1 - = MIN }\{1,4790 ; 2,8050 ; 3,7862\}=1,4907 \text { dan } \\
& \text { seterusnya. }
\end{aligned}
$$

Maka diperoleh data hasil penghitungan sebagai berikut:

Tabel 13. Solusi Ideal Positif dan Solusi Ideal Negatif

\begin{tabular}{|l|l|l|l|l|l|l|}
\hline Nilai A+ & 3.7862 & 2.5080 & 1.8740 & 2.3444 & 0.8485 & 1.3561 \\
\hline Nilai A & 1.7949 & 2.4770 & 1.4056 & 0.9377 & 1.4435 & 0.7265 \\
\hline
\end{tabular}

Sehingga diperoleh data sebagai berikut:

Tabel 14. Jarak Antara Nilai Terbobot Solusi Positif dan Solusi Negatif

\begin{tabular}{|c|c|}
\hline Nilai Solusi Positif & Nilai Solusi Negatif \\
\hline 2.5763 & 1.2059 \\
\hline 1.0986 & 2.3656 \\
\hline 1.6902 & 2.1441 \\
\hline
\end{tabular}

Selanjutnya peneliti menentukan nilai preferensi pada setiap alternatif sehingga ditemukan hasil sebagai berikut:

Tabel 15. Nilai Preferensi

\begin{tabular}{|c|c|c|}
\hline $\mathbf{C i}$ & Hasil & Rangking \\
\hline 0.2091 & KOS A1 & 3 \\
\hline 0.6871 & KOS A2 & 1 \\
\hline 0.6000 & KOS A3 & 2 \\
\hline
\end{tabular}

Berdasarkan penghitungan dengan menggunakan metode TOPSIS peneliti memperoleh hasil alternatif kost A2 sebagai kost terbaik dan paling ideal yang bisa dipilih oleh mahasiswa daerah Depok yang sedang mencari kost khusus putra yang Ideal. Kost A2 ini adalah Kost Griya Putra.

\section{KESIMPULAN}

Berdasarkan pada hasil penelitian, peneliti menarik kesimpulan bahwa adanya suatu sistem pendukung keputusan yang dapat diimplementasikan Pemilihan ini dilakukan dengan Metode TOPSIS, dimana berbagai criteria ditetapkan untuk dijadikan acuan pada penggunaan sistem pendukung keputusan ini yaitu diantaranya adalah fasilitas yang disediakan, keseimbangan biaya yang dikeluarkan dengan jatah uang perbulannya, tingkat keamanan, tingkat kebersihan, kenyamanan, dan jarak tempuh dari tempat kost ke kampus di sekitar daerah Depok. Peneliti memperoleh hasil berupa rangking yang ditampilkan sesuai dengan kriteria pencarian yang dilakukan oleh pengguna menggunakan metode perhitungan TOPSIS. Dari tiga kost alternatif, maka diputuskan bahwa kost
A2 yaitu Kost Griya Putra menempati peringkat pertama sebagai kost terbaik dan ideal.

\section{DAFTAR PUSTAKA}

[1] Arfida, S. (2013). Penerapan Metode TOPSIS dalam Sistem Pendukung Keputusan untuk Menentukan Pemenang Lomba Desa dan Kelurahan. J. Inform .

[2] Chamid, A. A. (2016). Penerapan Metode TOPSIS. Simetris .

[3] Ichsan. (2013). Sistem Pendukung Keputusan Pemilihan Penerima Beasiswa Mahasiswa Kurang Mampu Pada STMIK BUDIDARMA Medan Menerapkan Metode Profile Matching. Kursor , 5 (1), 2.

Marsono, W., \& Boy, A. F. (2015). Sistem Pendukung Pemilihan Keputusan Menu Makanan pada Penderita Obesitas Menggunakan TOPSIS. SAINTIKOM .

[5] Masrukin. (2020). Sistem Pendukung Pemilihan Keputusan Tempat Kost Menggunakan Metode Simpel Addictive Weightning (SAW). Jurnal Universitas Nusantara .

[6] Masruri. (2014). Sistem Pendukung Keputusan Pemilihan Tempat Kost Menggunakan Metode Simple Additive Weighting (SAW). Skripsi Universitas Nusantara PGRI Kediri: Kediri.

[7] Mulyanto, A. (2009). Sistem Informasi Konsem dan Aplikasi. Yogyakarta: Pustaka Pelajar.

[8] Nurcahyono, D., \& Metandi, F. (2015). Sistem Pendukung Keputusan dalam Memilih Kost dengan Menggunakan Sample Addictive Weighting (SAW) . garuda.ristekdikti.go.id .

[9] Pramuditha, A. (2017). Sistem Pendukung Keputusan Pemilihan Rumah Kost Putra untuk Mahasiswa di Kota Malang dengan Menggunakan Metode SAW. JITA .

[10] Rahadjeng, IR (2020). Decision Making In Determining CV. Sinar Siantar With The TOPSIS Technique

[11] Rutgiansyah, R. (2016). Sistem Pendukung Keputusan Pemilihan Dosen Berprestasi dengan Metode ANP dan TOPSIS. Semin .

[12] Sandy, G. E. (2016). Paper Group Project Sistem Pendukung Keputusan Metode TOPSIS dan Contoh Implementasi Kelas D. garuda.ristekdikti.go.id .

[13] Sugianto, H., \& Anra, H. (2016). Sistem Pendukung Keputusan Pemilihan Tempat Kost Khusus Mahasiswa Putra dengan Metode AHP dan TOPSIS berbasis WEB . garuda.ristekdikti.go.id. 